Page 23I - 246

\title{
Peningkatan Voluntarty Tax Compliance dan Kinerja Direktorat Jenderal Pajak
}

\author{
Dwi Sulistiani, Yona Octiani Lestari \\ UIN Maulana Malik Ibrahim Malang \\ dwisulistiani@pips.uin-malang.ac.id
}

\begin{abstract}
This study aimed to compare the tax revenue between before and after the implementation of Government Regulation No. 46 In 2013, and knowing the efectiveness of voluntary tax compliance' increase tax-payer for SMEs. The study was conducted by using a mixed method in which for the first goal using different test methods of quantitative premises while the second goal using qualitative descriptive method to illustrate the effectiveness of the regulation. The results showed that the tax revenue after the implementation of the regulation indeed there is a greater difference than before the implementation of these regulations. The second result shows that the application of the regulation is less effective in the first 5 months of implementation.
\end{abstract}

Key Words: voluntary tax compliance, performance, small and medium enterprise

\begin{abstract}
Abstrak
Penelitian ini bertujuan untuk membandingkan penerimaan pajak antara sebelum dan sesudah penerapan peraturan pemerintah nomor 46 tahun 2013, dan untuk mengetahui efektivitas voluntary tax compliance untuk meningkatkan wajib pajak di usaha kecil dan menengah. Penelitian ini menggunakan metode gabungan, dimana untuk menjawab tujuan pertama dengan metode kuantitatif. Sedangkan untuk menjawab tujuan kedua menggunakan metode deskriptif kualitatif. Hasil penelitian menunjukkan bahwa terdapat perbedaan penerimaan pajak antara sebelum dan sesudah penerapan regulasi ini. Hasil kedua menunjukkan bahwa penerapan peraturan ini kurang efektif dalam lima bulan pertama sesudah penerapan.
\end{abstract}

Kata Kunci: voluntary tax compliance, kinerja, usaha kecil dan menengah

Diterima: 2 April 2017; Revisi: 10 Juli 2017; Disetujui: I4 Agustus 2017 


\section{PENDAHULUAN}

Berlakunya sistem self assessment system di Indonesia menunjang besarnya peranan wajib pajak dalam menentukan besarnya penerimaan negara dari sektor pajak yang didukung oleh kepatuhan pajak (tax cimpliance). Kepatuhan wajib pajak merupakan pelaksanaan atas kewajiban untuk menyetor dan melaporkan pajak yang terutang sesuai dengan peraturan perpajakan. Kepatuhan yang diharapkan dengan sistem self assessment system adalah kepatuhan sukarela (valuntary compliance). Dalam meningkatkan kepatuhan sukarela dari Wajib Pajak, diperlukan keadilan dan keterbukaan dalam menerapkan peraturan perpajakan, kesederhanaan peraturan dan prosedur perpajakan serta pelayanan yang baik dan cepat dari Fiskus.

Menurut Mas'udi (20I4), pada era pajak sebagai upeti otomatis belum dikenal istilah "korupsi" sebagai konsep penyalahgunaan uang pajak oleh penguasa. Sebab, semua kebijakan penguasa, terutama terkait penggunaan uang pajak, adalah sah dan benar adanya. Jika uang pajak digunakan seluruhnya atau sebagian besar untuk kepentingan penguasa, itu hak mereka. Muhammad Rasulullah pun menegaskan: Tidak bakal masuk surga para pemungut dan pemakan uang pajak-upeti; La yadkhl al-jannah shahibu maksin (HR Ahmad).

Salah satu syarat pemungutan pajak adalah adil, karena itulah pemerintah mengeluarkan Peraturan Pemerintah nomor 46 tahun 2013 mengenai pajak untuk UMKM. Usaha mikro, kecil, dan menengah (UMKM) adalah merupakan sektor ekonomi yang mempunyai peran cukup besar dalam perekenomian nasional. Berdasarkan data Produksi Domestik Bruto (PDB) tahun 20II, UMKM mempunyai kontribusi kurang lebih 57\% total PDB. Namun demikian apabila dibandingkan dengan kontribusi UMKM terhadap penerimaan pajak, terdapat miss-match dimana kontribusi UMKM pada penerimaan perpajakan sangat kecil, yaitu kurang lebih $0.5 \%$ dari total penerimaan pajak. Ketidak imbangan kontribusi UMKM tersebut merupakan suatu indikasi bahwa tingkat ketaatan UMKM dalam memenuhi kewajiban perpajakan masih sangat rendah.

Dalam upanya untuk mendorong pemenuhan kewajiban perpajakan secara sukarela (voluntary tax compliance) serta mendorong kontribusi penerimaan negara dari UMKM, Pemerintah telah menerbitkan Peraturan Pemerintah Nomor 46 Tahun 2013 tentang Pajak Penghasilan atas Penghasilan dari Usaha yang Diterima atau Diperoleh Wajib Pajak yang Memiliki Peredaran Bruto Tertentu (PP NO. 46/20I3). Dalam 
Peraturan Pemerintah ini diatur pengenaan Pajak Penghasilan (PPh) yang bersifat final atas penghasilan yang diterima atau diperoleh Wajib Pajak dengan batasan peredaran bruto tertentu.

Salah satu alasan pemerintah menerbitkan PP No. 46 Tahun 2013 adalah untuk menyederhanakan pemungutan pajak untuk Usaha Mikro, Kecil dan Menengah (UMKM) yang mulai diberlakukan 0 I Juli 2013. Cara sederhana yang dimaksud adalah merubah dari pengenaan dari PPh Pasal 17 menjadi PPh Pasal 4 ayat 2 (final). Sesuai dengan Pasal 3 PP No. 46 Tahun 20I3, besaran tarif PPh final adalah sebesar 1\%, yang dikenakan dari penghasilan bruto. Selain itu juga untuk meningkatan kontribusi masyarakat dibidang pembangunan. Oleh karena itu sudah selayaknya PP NO. 46 dijadikan instrumen untuk menutup defisit penerimaan pajak di tiap-tiap Kantor Pelayanan Pajak setempat. Penelitian sebelumnya masih meneliti prediksi pajak dengan diterapkannya PP NO. 46 ataupun kepatuhan wajib pajak. Pada penelitian ini meneliti kenyataan yang terjadi setelah diterapkannya PP46, walaupun periode penerapannya masih terbatas 6 bulan. Periode yang diteliti adalah januari sampai dengan juni 2014 dibandingkan dengan periode sebelum diterapkannya PP46 yang diambil pada periode januari sampai dengan juni tahun 2013. Pengambilan tersebut digunakan setelah mengetahui pada kenyataannya meskipun periode penerapan PP46 dimulai pada juli 3014 namun masih banyak wajib pajak yang belum mengetahuinya sampai dengan akhir tahun 2013 dan baru menerapkannya di tahun 20I4. Penelitian ini bertujuan untuk: (I) Mengetahui apakah terdapat perbedaan penerimaan pajak antara sebelum dan sesudah diterapkannya PP No. 46 tahun 20I3; (2) Mengetahui bagaimanakan efektifitas peningkatan voluentary tax compliance pada wajib pajak yang tergolong dalam UMKM yang terlihat dari peningkatan jumlah NPWP yang terdaftar dan pelaporan dari wajib pajak UMKM dengan diterapkannya PP NO. 46 tahun 2013.

Dalam meneliti, peneliti membatasi penelitian hanya pada satu kota. Penelitian ini hanya dibatasi untuk Direktorat Jenderal Pajak di wilayah KPP Batu yang menaungi wajib pajak UMKM di Kota Batu. Periode penelitian juga hanya mengambil periode tahun 2013 dimana bulan januari sampai dengan juni sebagai periode sebelum diterapkannya PP No. 46 dan periode januari sampai dengan juni tahun 2014 sebagai periode setelah penerapan PP No. 46. 


\section{TINJAUAN KEPUSTAKAAN}

Terdapat beberapa peneliti yang meneliti mengenai kepatuhan wajib pajak UMKM, Pelitian lain juga meneliti mengenai penerapan akuntansi pajak atas PP No. 46 tahun 2013 untuk wajib pajak UMKM. Penelitian-penelitian tersebut seperti yang terlihat pada Tabel I.

\section{Tabel I. Ringkasan Penelitian Terdahulu}

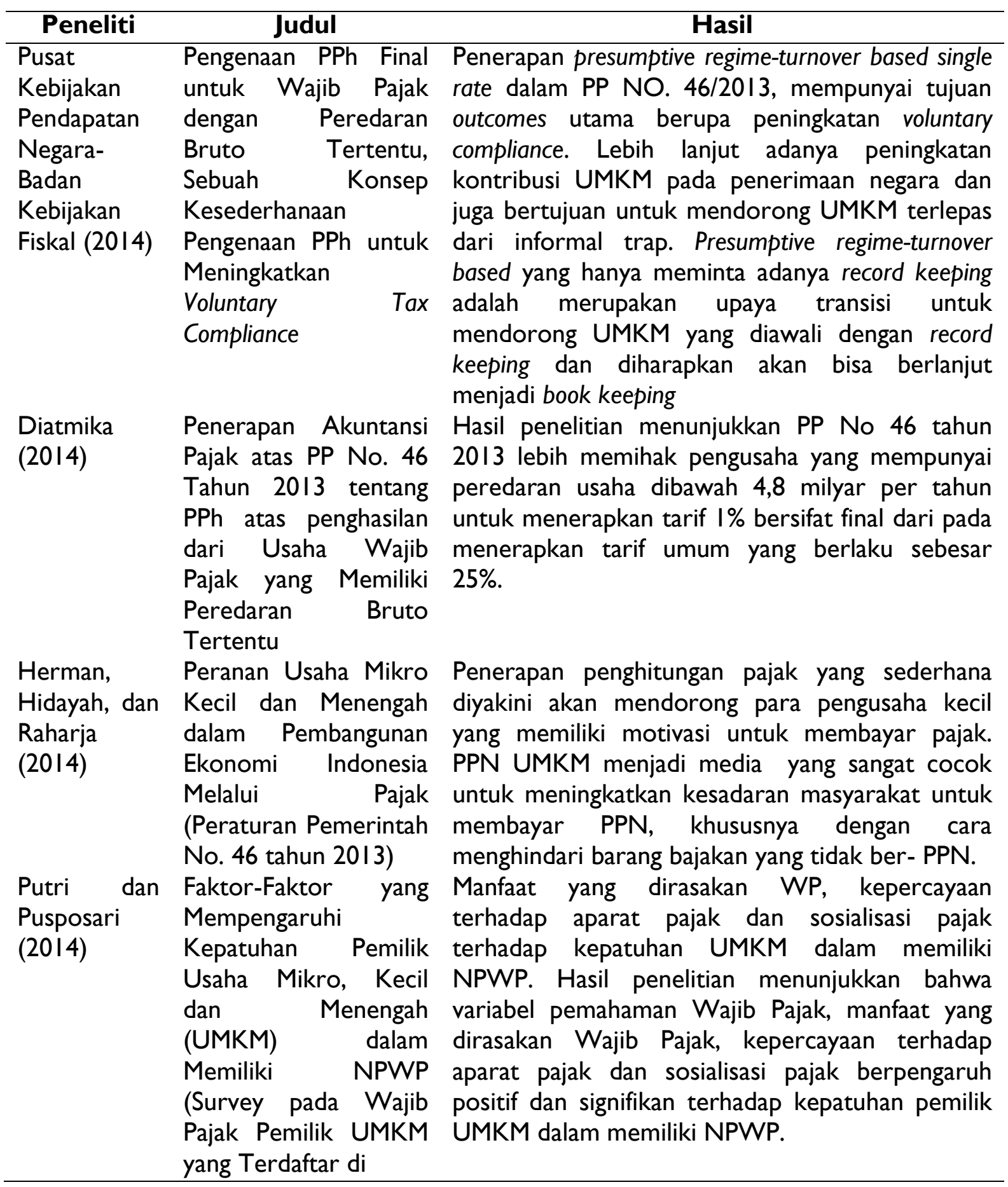




\begin{tabular}{|c|c|c|}
\hline Peneliti & Judul & Hasil \\
\hline & KPP Pratama Batu) & \\
\hline \multirow[t]{3}{*}{$\begin{array}{l}\text { Nilawati dan } \\
\text { Rusydi } \\
(20 \mid 4)\end{array}$} & $\begin{array}{lr}\text { Pengaruh } & \text { Kepuasan } \\
\text { atas } & \text { Pelayanan } \\
\text { Perpajakan } & \text { terhadap }\end{array}$ & $\begin{array}{l}\text { Hasil uji simultan menunjukkan bahwa bukti fisik, } \\
\text { keandalan, daya tanggap, keyakinan, dan empati } \\
\text { berpengaruh terhadap kepatuhan wajib pajak }\end{array}$ \\
\hline & Kepatuhan & UMKM di kota Malang. Hasil uji parsial \\
\hline & $\begin{array}{l}\text { Pajak UMKM di Kota } \\
\text { Malang Jawa Timur }\end{array}$ & $\begin{array}{l}\text { menunjukkan bahwa variabel bukti fisik, } \\
\text { keandalan, daya tanggap, dan empati tidak } \\
\text { berpengaruh secara signifikan terhadap kepatuhan } \\
\text { wajib pajak UMKM, sedangkan variabel keyakinan } \\
\text { berpengaruh secara signifikan terhadap kepatuhan } \\
\text { wajib pajak UMKM. }\end{array}$ \\
\hline
\end{tabular}

$\begin{array}{llr}\text { Fuadi dan } & \text { Pengaruh } & \text { Kualitas } \\ \text { Mangoting } & \text { Pelayanan } & \text { Petugas } \\ \text { (2014) } & \text { Pajak, } & \text { Sanksi } \\ & \text { Perpajakan } & \\ & \text { dan Biaya } & \text { Kepatuhan } \\ & \text { Pajak } & \text { Terhadap } \\ & \text { Kepatuhan } & \text { Wajib } \\ & \text { Pajak } & \\ & \text { UMKM } & \end{array}$

Hasil penelitian menunjukkan bahwa kualitas pelayanan dan sanksi perpajakan berpengaruh positif terhadap kepatuhan Wajib Pajak UMKM. Di samping itu, biaya kepatuhan pajak berpengaruh negatif terhadap kepatuhan Wajib Pajak UMKM.

Siregar, Pengaruh Pelayanan Saryadi dan Fiskus dan Listyorini (20I4)

Priambudi dan Rusydi (20I4) Nurmayanti (20I4)

\section{Pengetahuan}

Perpajakan terhadap Kepatuhan Wajib Pajak (Studi Empiris terhadap Wajib Pajak di Semarang)

Pengaruh Pemahaman Perpajakan, Tarif Pajak, Sanksi Pajak, Serta Pelayanan Pembayaran Pajak terhadap Kepatuhan Wajib Pajak UMKM di Kota Surabaya

Analisis Perbandingan Penerimaan Penghasilan dan Penerapan Tunggal
Pajak Sebelum Sesudah Trif dan
Hasil penelitian menunjukkan bahwa pelayanan fiskus dan pengetahuan pajak berpengaruh terhadap kepatuhan wajib pajak secara simultan.

Terdapat pengaruh pemahaman perpajakan yang dimiliki oleh WP terhadap kepatuhan WP UMKM di Kota Surabaya, tarif pajak berpengaruh terhadap kepatuhan WP di Kota Surabaya, terdapat pengaruh sanksi yang telah ditetapkan terhadap kepatuhan WP di Kota Surabaya dan pelayanan pembayaran pajak berpengaruh terhadap kepatuhan WP di Kota Surabaya.

Hasil penelitian (I) Penerimaan pajak penghasilan sebelum tarif tunggal mengalami peningkatan, (2) Penerimaan pajak penghasilan sesudah tarif tunggal mengalami peningkatan, (3) Uji beda penerimaan pajak penghasilan sebelum dan sesudah tarif tunggal yaitu terdapat perbedaan 


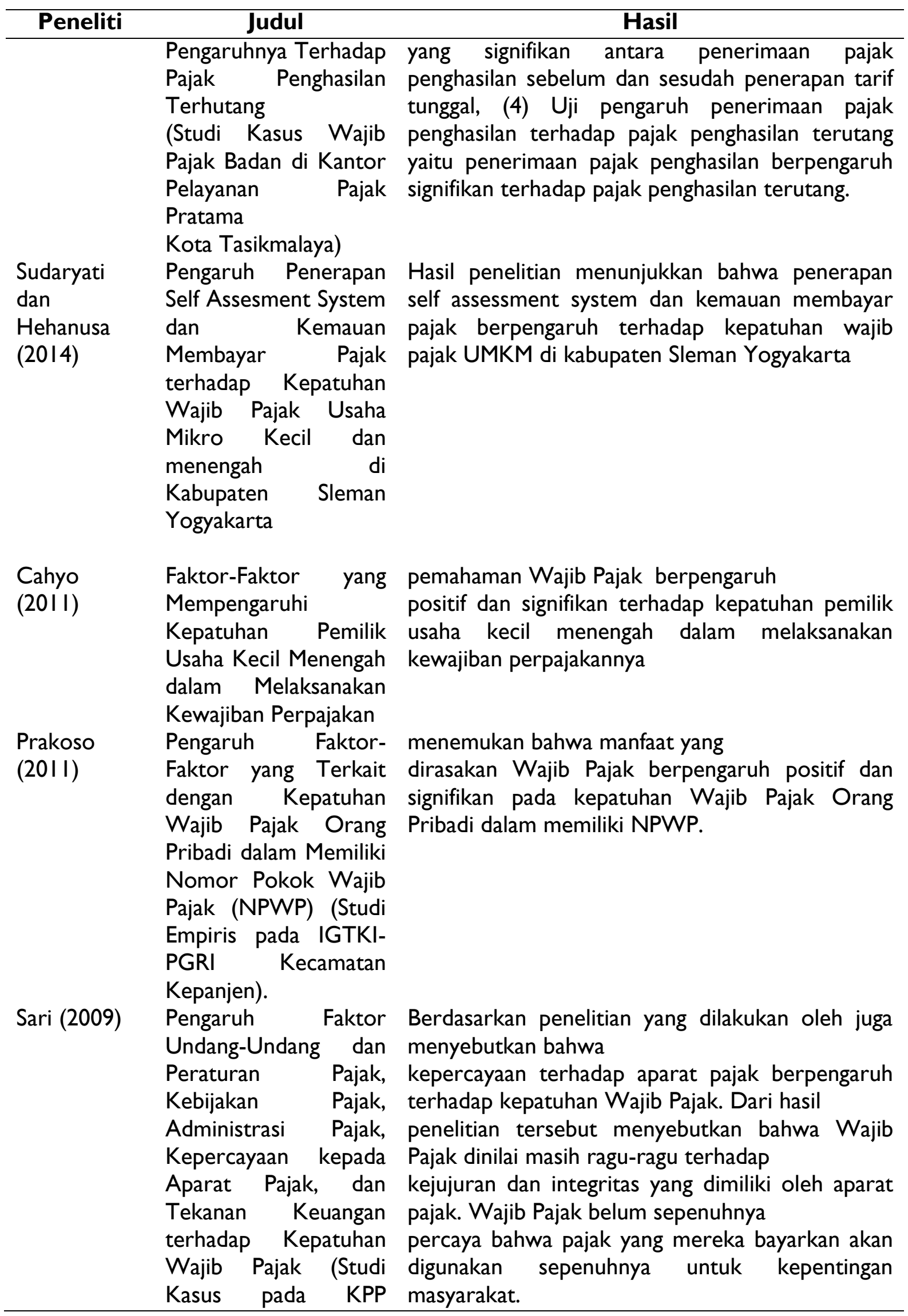




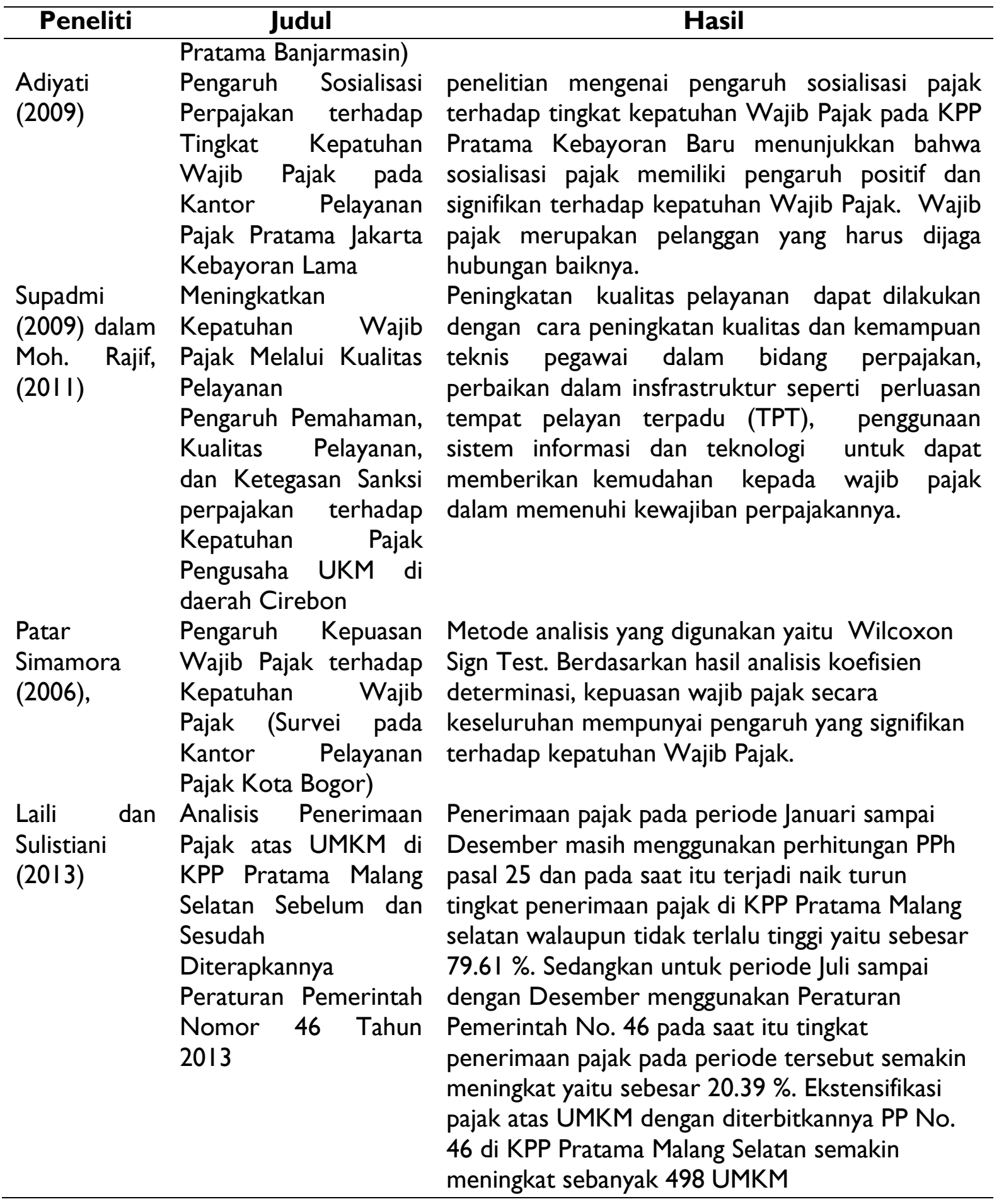

Berdasarkan penelitian-penelitian pada Tabel I dapat disimpulkan bahwa PP No. 46 membantu UMKM untuk mempermudah perhitungan pajak sehingga bagi DJP menguntungkan karena bisa meningkatkan voluentary tax compliance serta peningkatan penerimaan pajak. Penelitian diatas juga membuktikan bahwa kepuasan wajib pajak, sosialisai peraturan atau Undang-Undang, manfaat yang dirasakan, tarif pajak, dan 
kemudahan pemenuhan kewajiban perpajakan wajib pajak akan meningkatkan kepatuhannya. Diterbitkannya PP No. 46 juga membuat UMKM menjadi lebih dihargai, karena dengan adanya NPWP dan tuntutan untuk tertib administrasi, UMKM lebih dipercaya oleh Bank untuk mengajukan kredit sehingga mereka bisa mengembangkan usaha mereka menjadi lebih besar lagi.

Penelitian sebelumnya masih meneliti prediksi pajak dengan diterapkannya PP NO. 46 ataupun kepatuhan wajib pajak. Penelitian Laili dan Sulistiani (2013) yang menggunakan objek KPP Pratama Malang Selatan pada peride januri sampai dengan desember 2013 menemukan bahwa PP No. 46 masih belum efektif diterapkan oleh wajib pajak UMKM dalam wilayak KPP yang bersangkutan. Pada penelitian ini meneliti kenyataan yang terjadi setelah diterapkannya PP No. 46, walaupun periode penerapannya masih terbatas 6 bulan. Periode yang diteliti adalah januari sampai dengan juni 2014 dibandingkan dengan periode sebelum diterapkannya PP No. 46 yang diambil pada periode januari sampai dengan juni tahun 2013. Pengambilan tersebut digunakan setelah mengetahui pada kenyataannya meskipun periode penerapan PP No. 46 dimulai pada juli 3014 namun masih banyak wajib pajak yang belum mengetahuinya sampai dengan akhir tahun 2013 dan baru menerapkannya di tahun 2014.

\section{METODE}

Metode pengumpulan data dilakukan dengan cara mengumpulkan data kuantitatif berkaitan dengan data wajib pajak yang terdaftar di KPP Pratama Batu yang merupakan DJP yang menaungi wilayah Kotamadya Batu. Sesuai dengan perjanjian dengan pihak DJP maka peneliti tidak akan mengungkap identitas UMKM tersebut. Data yang dibutuhkan berupa: data jumlah NPWP yang terdaftar, data jumlah pajak yang dibayar dan data jumlah pelaporan yang masuk dari wajib pajak UMKM sebelum dan sesudah diterapakannya PP No. 46 tahun 2013. Data tersebut dibatasi untuk masa januari 2013 sampai dengan juni 20I4, dimana pada bulan januari sampai dengan juni 2013 merupakan periode sebelum penerapana PP No. 46 sedangkan periode januari sampai dengan juni 2014 merupakan periode sesudah penerapan PP No. 46. Periode tersebut diambil karena akan lebih tepat jika membandingkan pada masa yang sama tapi tahun yang berbeda daripada tahun yang sama tapi masa yang berbeda, karena ada beberapa perusahaan yang beroperasi musiman sehingga akan ada perbedaan jumlah 
omset dimasa yang berbeda. Selain itu pada bulan juli sampai dengan desember 2013 yang seharusnya PP46 sudah diterapkan, ternyata masih banyak UMKM yang belum menerapkannya, hal tersebut berdasarkan data yang ada di KPP Pratama Batu.

Metode penelitian ini menggunakan mix method dimana untuk menjawab tujuan pertama menggunakan metode kuantitatif dan untuk tujuan kedua menggunakan metode kualitatif. Analisis menggunakan metode deskriptif. Setelah semua data didapatkan maka langkah selanjutnya untuk menjawab tujuan pertama adalah melakukan: (I) Pengumpulan sampel dengan metode random sampling diambil 50 wajib pajak UMKM yang terdaftar di KPP Pratama Batu. Operasional variable; data sebelum diterapkannya PP No. 46 diambil dari PPh pasal 25 ditambah dengan I/I2 dari PPh pasal 29 yang merupakan pembayaran kurang bayar tahunan yang dibayar oleh wajib pajak, sedangkan data sesudah diterapkannya PP No. 46 dihasilkan dari pajak berdasar PP No. 46 yang dibayar. (2) Analisis data yaitu analisis deskriptif. Tujuan pembuatan statistik deskriptif adalah untuk melihat bagaimana struktur data yang digunakan dalam penelitian dan untuk memberi gambaran umum tentang data. Pembuatan statistik deskriptif dilakukan dengan menghitung jumlah data untuk masing-masing variabel. Berikutnya dilakukan perhitungan persentase jumlah masingmasing variabel tersebut, perhitungan mean, nilai maksimum, nilai minimum, dan standar deviasinya. (3) Uji hipotesis pertama untuk menguji beda antar periode sebelum dan sesudah diterapkannya PP No. 46 dengan menggunakan paired sample $t$ test yaitu pengujian untuk dua sampel yang berpasangan

Sedangkan untuk tujuan kedua yang dilakukan pada penelitian ini adalah: (I) Mengumpulkan data kuantitatif berkaitan dengan jumlah NPWP dan penerimaan pajak yang didapat dari wajib pajak UMKM dari periode januari 2013 sampai dengan juni 2014 agar tahu pergerakannya untuk mengukur efektifitas penerapan PP No. 46; (2) Mengumpulkan data kualitatif berupa wawancara pada pihak KPP Pratama Batu untuk meminta keterangan seputar Penerapan PP No. 46; (3) Menganalisis dengan metode deskriptif untuk data kuantitatif dan kualitatif yang telah diperoleh sebelumnya. 


\section{HASIL DAN PEMBAHASAN}

\section{Penerimaan Pajak Sebelum dan Sesudah Diterapkannya PP No. 46 Tahun} 2013

Berdasarkan data yang diperoleh dari sapel acak 50 wajib pajak UMKM dihasilkan penggambaran data melalui statistik deskriptif data pada Tabel 2.

Tabel 2. Statistik Deskriptif

\begin{tabular}{|c|c|c|c|c|}
\hline & $\begin{array}{c}\mathrm{N} \\
\text { Statistic }\end{array}$ & $\begin{array}{l}\text { Minimum } \\
\text { Statistic }\end{array}$ & $\begin{array}{l}\text { Maximum } \\
\text { Statistic }\end{array}$ & $\begin{array}{c}\text { Mean } \\
\text { Statistic }\end{array}$ \\
\hline sebelum & 50 & .00 & 3792400.00 & 355739.8200 \\
\hline sesudah & 50 & .00 & 3000000.00 & 658507.7200 \\
\hline $\begin{array}{l}\text { Valid } \\
\text { (listwise) }\end{array}$ & N 50 & & & \\
\hline
\end{tabular}

Sumber; Data diolah, 2014

Jumlah sampel yang diteliti adalah 50 dan semua data valid sehingga bisa digunakan dalam penelitian. Angka minimum dari data setoran pajak sebelum dan sesudah diterapkannya PP No. 46 adalah 0 atau tidak ada pembayaran. Sedangkan maksimum pembayaran pajak penghasilan UMKM sesuai Pasal 25 adalah Rp 3.792.400,dan pembayaran berdasar PP No. 46 adalah Rp 3.000.000,-. Rata-rata setoran pajak untuk periode sebelum $\operatorname{Rp}$ 355.740,- dan data sesudah $R_{p}$ 658.507. Berdasar data tersebut diatas menunjukkan bahwa rata-rata periode sesudah diterapkannya PP No. 46 lebih tinggi Rp 302.767,- . Artinya bahwa dengan adanya PP NO. 46 rata-rata penerimaan pajak untuk UMKM meningkat hampir 2 kali lipat dari sebelum dikeluarkannya PP NO. 46.

Hasil uji beda dengan menggunakan paired sample t-test menghasilkan data pada Tabel 3. Tabel 3 menunjukkan bahwa model penelitian ini menunjukkan hubungan sebesar 55\%, angka tersebut diatas 50\% sehingga model ini bisa diterima. Sedangkan pengujian mengenai perbedaan jumlah penerimaan pajak sebelum dan sesudah penerapan PP No. 46 tahun 2013 menunjukkan hasil yang signifikan dengan nilai sempurna yaitu 0,00. Hal ini mengartikan bahwa hipotesis pertama didukung bahwa "terdapat perbedaan penerimaan pajak antara sebelum dan sesudah diterapkannya PP No. 46". Sehingga hasil tersebut bisa menjawab maksud dan tujuan Direktorat Jenderal Pajak untuk meningkatkan penerimaan pajak dengan dikeluarkannya PP No. 46 tersebut. Hal tersebut dimungkinkan bahwa untuk perhitungan pajak UMKM 
sebelumnya masih dihitung dari laba, sehingga UMKM yang rugi tidak akan membayar pajak. Sedangkan sejak diberlakukannya PP No. 46 perhitungan pajak dihitung dari omset yaitu I\% dan bersifat final (tidak dapat dikreditkan), sehingga meskipun usahanya mengalami kerugian akan tetap dikenakan pajak $1 \%$ dari omset per bulannya. Ekstensifikasi pajak yang dilakukan oleh KPP Pratama Batu dengan mendatangi pengusaha UMKM yang masih belum ber NPWP untuk dihimbau agar manuanikan kewajibannya di bidang pajak juga bisa mempengaruhi besarnya jumlah pajak yang diterima setelah diberlakukannya PP No. 46.

Tabel 3. Hasil Uji Paired Samples t-test

\begin{tabular}{lrrrrr}
\hline & $\mathrm{N}$ & Correlation & Sig. & \\
\hline Pair I & sebelum \& sesudah & 50 & .552 & .000
\end{tabular}

Sumber: Data diolah, 2014

\section{Efektifitas peningkatan voluentary tax compliance dengan diterapkannya PP} No. 46

Efektifitas peningkatan voluentary tax compliance pada wajib pajak yang tergolong dalam UMKM yang terlihat dari peningkatan jumlah NPWP yang terdaftar dan pelaporan dari wajib pajak UMKM dengan diterapkannya PP NO. 46 tahun 2013. Dibawah ini hasil data keseluruhan yang berhubungan dengan wajib pajak UMKM di wilayah Kota Batu.

Tabel 4 Jumlah NPWP terdaftar dan setoran wajib pajak

\begin{tabular}{|c|c|c|c|c|c|c|}
\hline Masa & $\sum_{\text {NPWP }}$ & $\begin{array}{c}\% \text { pening } \\
\text { katan }\end{array}$ & PPh 25 & PP46 & PPh 29 & $\begin{array}{c}\text { Total } \\
\text { penerimaan }\end{array}$ \\
\hline Jan 2013 & 8980 & & 96.874 .225 & & 20.343 .840 & 117.218 .065 \\
\hline Peb 2013 & 9031 & $0,56 \%$ & III.|43.454 & & 43.329 .715 & 154.473 .169 \\
\hline Mar 2013 & 9075 & $0,48 \%$ & 159.183 .792 & & 252.751 .376 & 411.935 .168 \\
\hline Aprl 2013 & 9122 & $0,52 \%$ & 129.407 .476 & & 242.486 .385 & 371.893 .861 \\
\hline Mei 2013 & 9175 & $0,58 \%$ & I I8.744.155 & & II.605.178 & 130.349 .333 \\
\hline Juni 2013 & 9225 & $0,54 \%$ & 121.774 .470 & & 11.442 .315 & 133.216 .785 \\
\hline Juli 2013 & 9304 & $0,85 \%$ & 129.122 .870 & & 16.483.654 & | 45.606 .524 \\
\hline Agst 2013 & 9342 & $0,41 \%$ & 97.589 .986 & 18.105 .915 & 1.326 .700 & I I 7.022.60| \\
\hline Sept 2013 & 9398 & $0,6 \%$ & $104.017 .47 \mid$ & 70.865 .563 & 28.837 .524 & 203.720 .558 \\
\hline Okt 2013 & 9438 & $0,42 \%$ & 69.950 .845 & 70.511 .359 & 29.080 .213 & 169.542 .417 \\
\hline Nop 2013 & 9512 & $0,78 \%$ & 70.588 .349 & 84.282 .155 & 16.122 .999 & I 70.993.503 \\
\hline Des 2013 & 9931 & $4,4 \%$ & 68.930 .677 & | 38.406.866 & 52.520 .503 & 259.858 .046 \\
\hline Jan 2014 & 10083 & $1,5 \%$ & 56.428 .464 & I I8.305.029 & 6.420 .999 & 181.154 .492 \\
\hline Peb 2014 & 10357 & $2,7 \%$ & 50.828 .609 & 120.531 .918 & 10.476 .967 & 181.837 .494 \\
\hline Mar 2014 & 10545 & $\mathrm{I}, 8 \%$ & 58.742 .276 & 223.700 .839 & 249.110 .266 & 531.553 .381 \\
\hline Aril 2014 & 10716 & $1,6 \%$ & 39.490 .542 & 207.170 .164 & 170.460 .192 & 417.120 .898 \\
\hline Mei 2014 & 10819 & $0,95 \%$ & 37.857 .221 & 131.826 .485 & 7.905 .564 & I 77.589.270 \\
\hline \multirow[t]{2}{*}{ Juni 2014} & 10984 & $\mathrm{I}, 5 \%$ & 73.974 .417 & I54.865.266 & 34.013 .229 & 262.852 .912 \\
\hline & & & I.594.649.229 & I.338.57I.559 & 1.204 .717 .619 & 4.137 .938 .407 \\
\hline
\end{tabular}

Sumber; Data KPP Pratama Batu diolah, 2014 
Data yang diambil untuk tujuan kedua ini adalah pada masa pajak januari 2013 sampai dengan juni 2014, data tersebut diambil untuk mengetahui pergerakan jumlah NPWP dan jumlah setoran yang diterima dari periode sebelum dan sesudah penerapan PP No. 46. Data diatas adalah untuk keseluruhan wajib pajak yang terdaftar di KPP Pratama Batu baik yang masuk kategori UMKM ataupun yang tidak. Berdasarkan data di atas dapat dilihat bahwa terdapat peningkatan NPWP UMKM selama kurun waktu Januari 2013 sampai dengan Juni 2014. Selama kurun waktu tersebut terdapat dua peraturan pemerintah terkait pajak UMKM yaitu selama bulan Januari sampai bulan Juni menggunakan PPh Pasal 25 dan selama kurun waktu Juli 2013 sampai dengan Juni 2014 menggunakan PP No. 46. Namun meskipun PP No. 46 berlaku efektif pada bulan Juli 2013 pada kenyataannya di KPP Pratama Batu baru efektif pada bulan Agustus. Pada kurun waktu 12 bulan sejak bulan Juni 2013 diperoleh penambahan NPWP sebanyak $10.984-9.225=1.759$, dari hasil wawancara menyebutkan bahwa penambahan NPWP tersebut sekitar 90\% diantaranya (I.583) adalah wajib pajak UMKM. Dimana kriteria WP UMKM adalah baik WP Orang Pribadi atau Badan yang memenuhi syarat dalam PP No. 46.

Tingkat penerimaan pajak dengan menggunakan PPh Pasal 25 dengan tingkat penerimaan pajak dengan adanya Peraturan Pemerintah No. 46 lebih tinggi tingkat penerimaan pajak dengan menggunakan PPh Pasal 25. Hal tersebut terjadi karena tidak semua wajib pajak yang terdaftar di KPP Pratama Batu adalah WP UMKM, sehingga mereka tetap menggunakan PPh Pasal 25 untuk menghitung pajak atas penghasilannya. Mulai bulan Agustusterlihat pembayaran PPh pasal 25 makin menurun seiring dengan menaiknya pembayaran pajak sesuai PP No. 46. Pada bulan Maret dan April tiap tahunnya merupakan penerimaan pajak tertinggi bagi DJP karena pada bulan-bulan itu waktunya untuk bayar PPh pasal 29 atas kurang bayar pajak tahunan di tahun sebelumnya. Namun dilihat dari total keseluruhan penerimaan pajak penghasilan baik dari PPh pasal 25, pasal 29 dan PP No. 46 setelah masa Agustus 2013 terjadi peningkatan, hal ini membuktikan bahwa tujuan DJP dalam menerbitkan PP No. 46 ini tercapai. Peningkatan jumlah NPWP dan jumlah setoran yang masuk bisa mengindikasikan peningkatan voluentary tax compliance dari wajib pajak. UMKM.

Berdasarkan hasil observasi di lapangan tentang hambatan diberlakukannya Peraturan Pemerintah No. 46 menunjukkan bahwa ada banyak hambatan dengan 
diterapkannya Peraturan Pemerintah No. 46 yaitu ketidak mengertian wajib pajak dengan tatacara pengisian, perhitungan maupun tentang Peraturan Pemerintah No. 46 itu sendiri. Banyaknya hambatan yang dirasakan oleh wajib pajak menjadi tidak sesuai dengan tujuan diberlakukannya Peraturan Pemerintah No. 46 yaitu: (a) Kemudahan bagi masyarakat dalam melaksanakan kewajiban perpajakan; (b) Meningkatkan pengetahuan tentang manfaat perpajakan bagi masyarakat; (c) Terciptanya kondisi kontrol sosial dalam memenuhi kewajiban perpajakan.

Adanya hambatan tersebut dikarenakan kurangnya sosialisasi secara mendalam tentang Peraturan Pemerintah No. 46 sehingga yang seharusnya mulai efektif berlaku di bulan Juli menjadi bulan Agustus. Pada bulan Juli KPP Pratama Batu masih mengadakan sosialisasi dengan wajib pajak yaitu dengan mengirimkan surat pemberitahuan adanya Peraturan Pemerintah No. 46 dengan wajib pajak dan juga dengan membuka kelas kursus pajak UMKM. Dengan adanya sosialisasi yang mendalam mengenai teknis pengisian, perhitungan dan tatacara pelaporan serta dengan adanya pendekatan secara personal dimungkinkan akan mendapatkan pemahaman yang baik dan terlaksananya perpajakan oleh wajib pajak di kawasan KPP Pratama Batu.

Sedangkan dari pengamatan peneliti, dalam pelaksanaan Peraturan Pemerintah No. 46 tersebut masih kurang efektif. Hal ini dikarenakan diberlakukannya Peraturan Pemerintah No. 46 dengan di efektifkannya peraturan tersebut hanya memiliki jangka waktu I (satu) bulan dari tanggal diterbitkannya. Sedangkan jangka I (satu) bulan tersebut tidak cukup jika hanya dengan mensosialisasikan peraturan baru yang berakibatkan tidak mengertinya wajib pajak yang bersangkutan dengan peraturan baru tersebut. Dalam membuat peraturan baru, pemerintah seharusnya memberikan jangka waktu minimal 6 (enam) bulan untuk sosialisasi. Sehingga adanya peraturan baru yaitu Peraturan Pemerintah No. 46 akan lebih efektif dan terlaksana dengan baik jika peraturan tersebut disosialisasikan pada 6 (enam) bulan setelah dikeluarkannya Peraturan Pemerintah No. 46 tersebut. Hal itu bisa dibuktikan dari data diatas bahwa mulai bulan Desember 2013 terdapat peningkatan yang signifikan dalam pembayaran pajak berdasar PP No. 46 dan dalam jumlah NPWP ada kenaikan 4,4\% dimana pada periode sebelumnya kurang dari I\%.

Berdasar data tersebut antara tingkat penerimaan pajak dengan menggunakan PPh Pasal 25 dengan tingkat penerimaan pajak dengan adanya Peraturan Pemerintah 
No. 46 lebih tinggi tingkat penerimaan pajak dengan menggunakan PPh Pasal 25. Adanya peningkatan penerimaan pajak dengan adanya Peraturan Pemerintah No. 46 sudah baik. Akan tetapi kontribusinya terhadap penerimaan pajak sedikit dan lebih besar jika menggunakan PPh Pasal 25. Hal ini terjadi karena wajib pajak yang membayar dengan PPh Pasal 25 adalah WP yang mempunyai omset ditas 4,8 milyar ataupun yang sudah terkena pajak final lainnya, sehingga lumrah jika penerimaan dari mereka lebih besar dari WP UMKM yang notabene adalah pengusaha mikro, kecil dan menengah yang masih perlu bantuan dari pemerintah. Hal ini justru menunjukkan prinsip keadilan telah ditegakkan dalam pungutan pajak di Indonesia, tapi meskipun demikian setidaknya pajak dari UMKM bisa menyumbangkan 30\% dari total pajak di KPP Pratama Batu. Itu angka yang cukup bagus dalam peningkatan kinerja Direktorat Jenderal Pajak khususnya KPP Pratama Batu.

\section{SIMPULAN}

Berdasarkan hasil penelitian diatas dapat disimpulkan bahwa pada tujuan pertama penelitian ini telah terbukti bahwa terdapat perbedaan penerimaan pajak antara sebelum dan sesudah diterapkannya PP No. 46 tahun 2013. Hal tersebut dimungkinkan bahwa untuk perhitungan pajak UMKM sebelumnya masih dihitung dari laba, sehingga UMKM yang rugi tidak akan membayar pajak. Tujuan kedua dari penelitian ini untuk mengetahui efektifitas penerapan PP NO. 46 menunjukkan bahwa penerapan PP No. 46 masih kurang efektif pada 5 bulan pertama penerapannya. Hambatan berupa penerbitan PP No. 46 yang terkesan mendadak yaitu I bulan sebelum efektif diterapkan menyebakan adanya kemunduran penerapan yang harusnya bulan juli menjadi bulan agustus 2013 .

\section{PUSTAKA ACUAN}

Adiyati, Tatiek. 2009. Pengaruh Sosialisasi Perpajakan terhadap Tingkat Kepatuhan Wajib Pajak pada Kantor Pelayanan Pajak Pratama Jakarta Kebayoran Lama. Skripsi (SI). Akuntansi. Fakultas Ekonomi. Universitas Pembangunan Nasional.

Cahyo, Gatut Wahyu Tri. 20II. Faktor-Faktor yang Mempengaruhi Kepatuhan Pemilik Usaha Kecil Menengah dalam Melaksanakan Kewajiban Perpajakan. Skripsi (SI). Akuntansi. Fakultas Ekonomi dan Bisnis. Universitas Brawijaya Malang. 
Fuadi, AO dan Yenni Mangoting. 2013. Pengaruh Kualitas Pelayanan Petugas Pajak, Sanksi Perpajakan dan Biaya Kepatuhan Pajak Terhadap Kepatuhan Wajib Pajak UMKM. Tax \& Accounting Review, Vol. I, No.I

Herman, Nurul Hidayah dan Liana Raharja. 2013. Peranan Usaha Mikro Kecil dan Menengah dalam Membangun Ekonomi Indonesia Melalui Pajak (Peraturan Pememrintah No. 46 Tahun 2013). Jurnal. Universitas Mercu Buana.

Nilawati, Hesti Chandra. 2012. Pengaruh Kepuasan atas Pelayanan Perpajakan terhadap Kepatuhan Wajip Pajak UMKM di Kota Malang Jawa Timur The Influence of Satisfaction to SME's Tax Payer Compliance in Malang of East Java. Jurnal. Universitas Brawijaya: Malang.

Nurmayanti, Irma. 20I2. Analisis Perbandingan Penerimaan Pajak Penghasilan Sebelum dan Sesudah Penerapan Tarif Tunggal dan Pengaruhnya terhadap Pajak Penghasilan Terutang (Studi Kasus Wajip Pajak Badan di Kantor Pelayanan Pajak Pratama Kota Tasikmalaya). Skripsi. Universitas Siliwangi: Tasikmalaya.

Prakoso, Iswanto Priyo. 2012. Pengaruh Faktor-Faktor yang Terkait dengan Kepatuhan Wajib Pajak Orang Pribadi dalam Memiliki Nomor Pokok Wajib Pajak (NPWP) (Studi Empiris pada IGTKI-PGRI Kecamatan Kepanjen). Skripsi (SI). Akuntansi. Fakultas Ekonomi dan Bisnis. Universitas Brawijaya Malang.

Rajif, Mohamad. 20II. Pengaruh Pemahaman, Kualitas Pelayanan, dan Ketegasan Sanksi perpajakan terhadap Kepatuhan Pajak Pengusaha UKM di daerah Cirebon. Jakarta: Universitas Gunadarma.

Sari, Yohana Yustika. 2009. Pengaruh Faktor Undang-Undang dan Peraturan Pajak, Kebijakan Pajak, Administrasi Pajak, Kepercayaan kepada Aparat Pajak, dan Tekanan Keuangan terhadap Kepatuhan Wajib Pajak (Studi Kasus pada KPP Pratama Banjarmasin). Thesis (S2). Akuntansi. Fakultas Ekonomi dan Bisnis. Universitas Brawijaya Malang.

Simamora, Patar. 2006. Pengaruh Kepuasan Wajib Pajak terhadap Kepatuhan Wajib Pajak (Survei pada Kantor Pelayanan Pajak Kota Bogor). [Tesis]. Jakarta: Program Pasca Sarjana Ilmu Administrasi Universitas Indonesia

Siregar, YA, Saryadi dan Sari Listyorini. diunduh 2014. Pengaruh Pelayanan Fiskus dan Pengetahuan Perpajakan terhadap Kepatuhan Wajib Pajak (Studi Empiris 
terhadap Wajib Pajak di Semarang). Jurnal Ilmu Administrasi Bisnis. Universitas Diponegoro

Supadmi, Niluh. 2006. Meningkatkan Kepatuhan Wajib Pajak Melalui Kualitas Pelayanan. Jurnal Skripsi. Jurusan Akuntansi. Universitas Udayana. 